\title{
Bilateral adrenal non-Hodgkin's lymphoma with adrenal insufficiency
}

\author{
R D Ellis, D Read
}

\begin{abstract}
A 74 year old women presented with lethargy and weight loss and was found to have profound adrenal insufficiency and bilateral adrenal mass lesions. Histological examination revealed non-Hodgkin's lymphoma. There was no evidence of lymphoma outside the adrenal glands. Isolated bilateral adrenal masses may rarely be due to primary adrenal nonHodgkin's lymphoma, which is often associated with adrenal insufficiency.

(Postgrad Med F 2000;76:508-509)
\end{abstract}

Keywords: lymphoma; adrenal insufficiency

Case report

A 74 year old women presented with a three month history of general ill health with lethargy, weight loss, non-specific abdominal pains, and constipation. There was a past history of angina pectoris and hypertension. Treatment with methyldopa had been stopped one week before admission to hospital because of hypotension (blood pressure 110/80 mm $\mathrm{Hg})$. There were no clinical signs of adrenal insufficiency apart from mild dehydration and moderate postural hypotension (blood pressure 140/80 mm $\mathrm{Hg}$ supine, 100/70 mm Hg erect).

Initial investigations revealed a normal full blood count, blood film, and erythrocyte sedimentation rate. Serum electrolyte estimation revealed a sodium concentration of $137 \mathrm{mmol} / 1$ (normal range 136-148) and potassium concentration of $5.0 \mathrm{mmol} / 1(3.8-5.0)$. There was a raised urea concentration of $13.7 \mathrm{mmol} / 1$ (2.8-6.5) and creatinine concentration of 170 $\mathrm{mmol} / \mathrm{l}(60-120)$. The serum calcium concentration was raised at $2.97 \mathrm{mmol} / 1(2.20-2.60)$ with an albumin concentration of $44 \mathrm{~g} / 1$ (35-52) and phosphate concentration of 1.17 $\mathrm{mmol} / \mathrm{l}(0.80-1.40)$, but the serum calcium concentration quickly returned to normal after intravenous rehydration with normal saline.

Department of Medicine, Colchester General Hospital, UK R D Ellis

D Read

Correspondence to: Dr R D Ellis, Department of Gastroenterology, Chelsea and Westminster Hospital, 396 Fulham Road, London SW10 9NH, UK

Submitted 15 July 1999 Accepted 14 January 2000

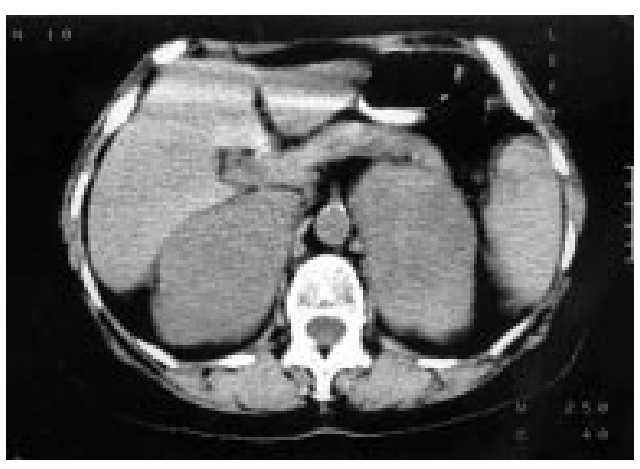

Figure 1 Computed tomogram with intravenous enhancement showing bilateral adrenal mass lesions.

\section{Summary points}

- Isolated bilateral adrenal masses are usually metastases, most commonly from bronchial carcinomas, but may rarely be due to primary bilateral adrenal lymphoma.

- Primary bilateral adrenal lymphoma is commonly associated with adrenal insufficiency.

- The prognosis of primary bilateral adrenal lymphoma is poor.

Serum parathyroid hormone concentration was $15 \mathrm{pg} / \mathrm{ml}$ (10-65). Liver function tests, protein electrophoresis, and immunoglobulin concentrations were normal.

A short adrenocorticotrophic hormone stimulation test revealed adrenal insufficiency with a baseline cortisol concentration of 5 nmol/1 (150-680) with no rise at 30 and 60 minutes.

Computed tomography with intravenous enhancement of the abdomen and pelvis revealed bilateral, $10 \mathrm{~cm}$ adrenal mass lesions that were partially necrotic (fig 1). Histological examination of a percutaneous computed tomography guided biopsy specimen revealed a diffuse B-cell non-Hodgkin's lymphoma of centrocytic/centroblastic type. Immunohistochemistry demonstrated expression of bcl-2 protein confirming follicle centre cell origin.

A bone marrow biopsy specimen and aspirate showed no morphological evidence of infiltration by lymphoma, although immunophenotyping by flow cytometry was not performed. A chest radiograph was normal and there was no lymphadenopathy on clinical examination.

Primary bilateral adrenal non-Hodgkin's lymphoma with adrenal insufficiency was diagnosed. Treatment with glucocorticoid and mineralocorticoid hormone replacement therapy was started. Chemotherapy with intravenous cyclophosphamide, Adriamycin, vincristine, and prednisolone was administered. The patient then became neutropenic and developed an Escherichia coli septicaemia. This was successfully treated but the general condition of the patient deteriorated and she died three weeks after starting chemotherapy. A request for postmortem examination was refused by the family.

\section{Discussion}

Adrenal masses are usually metastases from malignant tumours, most often from bronchial carcinomas. ${ }^{1}$ Non-Hodgkin's lymphoma affecting the adrenal glands is usually associated with other sites of disease, most usually the 
Table 1 Previously reported cases of bilateral primary adrenal non-Hodgkin's lymphoma

\begin{tabular}{|c|c|c|c|c|c|c|c|c|}
\hline Paper & Age & Sex & Presentation & Diagnosis & Histology & hypoadrenal & Treatment & Survival \\
\hline Feldberg et al & 43 & Male & $\begin{array}{l}\text { Abdominal pain, fever, } \\
\text { hypertension, hypercalcaemia }\end{array}$ & $\mathrm{CT}$ & $\begin{array}{l}\text { Diffuse histiocytic } \\
\text { lymphoma }\end{array}$ & No & $\begin{array}{l}\text { Chemotherapy (reduction in size } \\
\text { of masses on CT at } 2 \text { months) }\end{array}$ & $?$ \\
\hline Ito $e t a l^{6}$ & 47 & Male & $\begin{array}{l}\text { Transverse myelitis: incidental } \\
\text { finding of lymphoma }\end{array}$ & $\mathrm{CT}$ & Diffuse large cell & No & $\begin{array}{l}\text { Chemotherapy: MACOP-B }{ }^{\star} \\
\text { (reduction in size of mass on CT) }\end{array}$ & 5 months \\
\hline Aron $e t a l^{7}$ & 70 & Male & $\begin{array}{l}\text { Abdominal pain, lethargy, } \\
\text { vomiting }\end{array}$ & Postmortem & Reticulum cell sarcoma & Yes & None & 1 week \\
\hline Pagliuca $e t a l^{8}$ & 59 & Male & $\begin{array}{l}\text { Vomiting, lethargy, weight } \\
\text { loss, night sweats }\end{array}$ & $\mathrm{CT}$ & $\begin{array}{l}\text { High grade B-cell } \\
\text { lymphoblastic }\end{array}$ & Yes & Chemotherapy: CHOP† & 1 month \\
\hline Domenici $^{9}$ & 52 & Female & Fever, weight loss & Postmortem & & & None & \\
\hline Shea et al ${ }^{10}$ & 81 & Male & Back pain & CT & Immunoblastic lymphoma & Yes & None & 2 months \\
\hline Sparagana $^{11}$ & 71 & Male & $\begin{array}{l}\text { Nausea, weight loss, fever, } \\
\text { weakness }\end{array}$ & Postmortem & Reticulum cell sarcoma & Yes & None & 1 week \\
\hline $\begin{array}{l}\text { Alvarez-Costello }{ }^{12} \\
\text { Case } 1\end{array}$ & 59 & Female & $\begin{array}{l}\text { Abdominal pain, weakness, } \\
\text { weight loss }\end{array}$ & CT & Large cell pleomorphic & No & $\begin{array}{l}\text { Chemotherapy (regression of } \\
\text { masses on serial CT scans) }\end{array}$ & $?$ \\
\hline $\begin{array}{l}\text { Alvarez-Costello }{ }^{12} \\
\quad \text { Case } 2\end{array}$ & 69 & Male & $\begin{array}{l}\text { Abdominal pain, weakness, } \\
\text { weight loss }\end{array}$ & CT & Large cell & No & $\begin{array}{l}\text { Chemotherapy (resolution of } \\
\text { masses on CT) }\end{array}$ & ? \\
\hline
\end{tabular}

${ }^{\star}$ MACOP-B is a combination of methotrexate, Adriamycin, cyclophosphamide, vincristine, prednisolone, and bleomycin

†CHOP is a combination of cyclophosphamide, adriamycin, vincristine, and prednisolone.

$\mathrm{CT}=$ computed tomography.

retroperitoneal lymph nodes and ipsilateral kidney. $^{2}$ Adrenal involvement in widespread non-Hodgkin's lymphoma occurs in $4 \%$ of cases as assessed by computed tomography ${ }^{3}$ and in $24 \%$ at postmortem examination. ${ }^{4}$ Disease arising in, and confined to, the adrenal glands is unusual and is termed primary adrenal lymphoma. The adrenal gland in man contains no lymphoid tissue, and the follicle centre cell origin of this lymphoma suggests the tumour may have arisen on a background of previous autoimmune adrenalitis, consistent with the finding of profound adrenal insufficiency. Bilateral primary adrenal nonHodgkin's lymphoma is rare, with only nine previous cases reported, all occurring in patients over 40 years of age ${ }^{5-12}$ Five cases were treated with chemotherapy with decrease in adrenal mass size in four cases with maximum reported survival of five months (see table 1). In the present case, the patient died three weeks after starting combination chemotherapy. An alternative treatment strategy would be to administer an oral alkylating agent, or local radiotherapy.

Adrenal insufficiency due to adrenal involvement in widespread non-Hodgkin's lymphoma was previously thought to be rare, but in a recent series there were four cases out of 127 patients. ${ }^{13}$ However, adrenal insufficiency is more common in bilateral primary adrenal
non-Hodgkin's lymphoma, occurring in half of the reported cases including this case..$^{9-11}$

Isolated bilateral adrenal masses may be due to primary adrenal non-Hodgkin's lymphoma that is often associated with adrenal insufficiency and carries a poor prognosis.

1 Glomset DA. The incidence of metastasis of malignant tumours to the adrenals. Am $\mathcal{F}$ Cancer 1938;32:57-61.

2 Glazer HS, Lee JK, Balfe DM. Non-Hodgkin's lymphoma: computed tomography demonstration of unusual extranodal involvement. Radiology 1983;149:211-17.

3 Paling MR, Williamson BRJ. Adrenal involvement in non-Hodgkin's lymphoma. AfR Am F Roentgenol 1983;141: 303-5.

4 Rosenberg SA, Diamond HD, Jaslowitz B. Lymphosarcoma: a review of 1269 cases. Medicine (Baltimore) 1961;40:31-84.

5 Feldberg MA, Hendriks MJ, Klinkhammer AC. Massive Feldberg MA, Hendriks MJ, Klinkhammer AC. Massive
bilateral non-Hodgkin's lymphoma of the adrenals. Urol
Radiol 1986;8:85-8.

6 Ito Y, Yamaha M, Koide T, et al. A case of bilateral adrenal non- Hodgkin's lymphoma. Acta Urol Fpn 1988;34:137-40. 7 Aron E, Jobard P, Groussin P, et al. Bilateral and primary lymphosarcoma of the adrenal glands. Semaine des Hopitaux 1971;47:3067-71.

8 Pagliuca A, Gillett DS, Salisbury JR, et al. Bilateral adrenal lymphoma presenting as Addison's disease. Postgrad Med $\mathcal{F}$ 1989;65:684-6.

9 Domenici A. Bilateral destructive lymphosarcoma of the adrenals. Pathologica 1948;40:104-10.

10 Shea TC, Spark R, Kane B, et al. Non-Hodgkin's lymphoma limited to the adrenal gland with adrenal insufficiency. $A m \mathcal{F}$ Med 1985;78:711-14.

11 Sparagana M. Addison's disease due to reticulum cell sarcoma apparently limited to the adrenals. $\mathcal{f} \mathrm{Am}$ Geriatric Soc 1970;18:550-4.

12 Alvarez-Costello A. Computed tomography of primary lymphoma of the adrenal area. F Ultrasound Med 1993:17: lymphom 408 .

13 Gamelin E, Beldent V. Non-Hodgkin's lymphoma presenting with primary adrenal insufficiency. A disease with an underestimated frequency? Cancer 1992:69:2333-6. 